$\underset{\substack{\mathrm{p}-\text { ISSN 2548-8201 | e-ISSN 2580-0469 } \\ \text { https://ummaspul.e-journal.id/maspuljr/ }}}{\operatorname{MNSMUL}}$

\title{
Analisis Kebutuhan Penyusunan Perangkat Pembelajaran Tematik Berbasis HOTS (Higher of Order Thinking Skills) pada Kurikulum 2013 di SD Muhammadiyah 05 Batu
}

\author{
Tyas Deviana ${ }^{\otimes}$, Dian Ika Kusumaningtyas ${ }^{2}$ \\ 1,2(PGSD, Universitas Muhammadiyah Malang, Malang-Indonesia \\ $\bowtie$ Corresponding email: 1tyasdefiana@umm.ac.id
}

\begin{abstract}
Received: 01-09-2019
Accepted: 03-10-2019

Published: 07-10-2019

Abstrak. Pelaksanaan pembelajaran di SD Muhammadiyah 5 Batu masih baru menerapkan kurikulum 2013. Kondisi tersebut menjadikan guru belum sepenuhnya memahami konsep K13 dengan baik. Termasuk juga terkait penyusunan perangkat pembelajaran. Perangkat yang digunakan guru belum memenuhi tingkat kemampuan berpikir yang HOTS (Higher of Order Thinking Skilss) hal ini terbukti dari tujuan pembelajaran yang ada pada RPP yang dibuat hanya pada tataran level 1 (C1 - C2). Suatu perangkat pembelajaran dikatakan HOTS (Higher of Order Thinking Skills) apabila kegiatan pembeljaran yang ada didalamnya didonimasi dengan kegiatan pembelajaran kognitif level 3 yaitu pada C4 - C6. Kondisi awal di lapangan menunjukkan bahwa, kegiatan pembelajaran yang ada pada RPP hanya cooperative learning dan diskusi kelompok maupun diskusi kelas, kegiatan pembelajaran kurang bervariasi. Melihat kondisi yang telah dipaparkan, maka dirasa perlu untuk meneliti lebih lanjut tentang analisis kebutuhan penyusunan perangkat pembelajaran berbasis HOTS pada K13. Analisis kebutuhan penyusunan perangkat pembelajaran berbasis HOTS ini meliputi analisis kurikulum, analisis peserta didik, serta analisis situasi lapangan. Analisis dari beberapa aspek perlu dilakukan untuk mengetahui gambaran kebutuhan akan dikembangannya suatu perangkat pembelajaran dalam bentuk RPP yang berbasis HOTS secara menyeluruh sesuai dengan kondisi peserta didik, kurikulum, serta situasi lapangan. Selain itu agar diperoleh gambaran secara menyeluruh dan komprehensif terkait kondisi pembelajaran dan perangkat pembelajaran di SD Muhammadiyah 5 Batu.
\end{abstract}

Kata kunci: Analisis Kebutuhan, Perangkat Pembelajaran, HOTS

\begin{abstract}
The implementation of learning in SD Muhammadiyah 5 Batu is still new in implementing the 2013 curriculum. Related is also related to learning tools. The tools used by the teacher have not yet reached the level of HOTS (Higher of Order Thinking Skills) thinking ability as evidenced from the learning objectives in the RPP that are made only at the level 1 level (C1 - C2). Where the learning kit announces HOTS (Higher Level Thinking Skills) asking for learning activities in it to be synonymous with cognitive level 3 learning activities, namely at C4 - C6. The initial conditions in the field indicate that learning activities in the RPP are only cooperative learning and group discussions or class discussions, learning activities are less varied. Seeing the conditions that have been described, it is deemed necessary to further improve the analysis of HOTS-based device installation needs in K13. The analysis of the needs of the preparation of HOTS-based tools discusses curriculum analysis, student analysis, and analysis of field considerations. Analysis of some aspects that need to be done to study the description of the need to be developed in a learning application in the form of RPP based on HOTS that suits the needs of students, curriculum, and also the field. In addition, in order to obtain a complete and complete picture related to learning and learning tools in SD Muhammadiyah 5 Batu.
\end{abstract}

Keywords : Need assesment, Lesson plan, HOTS 


\section{PENDAHULUAN}

Pendidikan mempunyai peranan penting dalam suatu negara untuk menjamin kelangsungan negara dan bangsa, karena pendidikan merupakan pondasi untuk meningkatkan dan mengembangkan kualitas sumber daya manusia yang unggul dan berkarakter secara akademik maupun non akademik. Penyelenggaraan pendidikan memiliki tujuan untuk mencerdaskan kehidupan pada semua aspek perkembangan peserta didik, karena pada dasarnya setiap peserta didik memiliki semua kecerdasan yang harus dioptiimalkan. Hal ini sejalan dengan Undang-Undang No. 20 tahun 2003 tentang Sistem Pendidikan Nasional yang menyatakan bahwa pendidikan nasional berfungsi untuk mengembangkan kemampuan (kompetensi) dan membentuk watak (karalter) bangsa serta peradaban bangsa yang bermartabat dalam rangka mencerdaskan kehidupan bangsa. Salah satu cara untuk meningkatkan pengembangan kualitas sumber daya manusia (SDM) yaitu dengan perbaikan dan pengembangan pembelajaran dan penilaian sesuai dengan kurikulum yang berlaku. Perbaikan dan pengembangan pembelajaran ini dilaksanakan terutama pada jenjang Sekolah Dasar (SD), karena pada jenjang SD merupakan dasar pendidikan untuk jenjang selanjutnya.

Pendidikan dan pembelajaran pada jenjang Sekolah Dasar (SD) merupakan landasaan dan pondasi pada pendidikan formal yang mempengaruhi pendidikan dan pembelajaran peserta didik pada jenjang selanjutnya. Bentuk pengembangan proses pembelajaran pada jenjang SD yaitu melalui pembelajaran tematik. Pendekatan pembelajaran tematik dilaksanakan di SD dikarenakan pola piker dan karakteristik peserta didik pada usia SD bersifat holistik (menyeluruh) dan operasional konkret. Pelaksanaan pembelajaran tematik di SD bertujuan agar peserta didik mampu mengenal lingkungan sendiri secara utuh dan menyeluruh, harapannya peserta didik dapat menyelesaikan permasalahan yang dihadapi di lingkungan sekitarnya. Sehingga tidak ada anggapan bahwa materi di sekolah hanya untuk mengejar nilai, dan tidak bisa diaplikasikan dalam menyelesaikan masalah dalam kehidupan sehari-hari.

Kurikulum 2013 pada jenjang Sekolah Dasar (SD) menggunakan pendekatan pembelajaran tematik. Menurut pendapat Akbar (2013: 69) pembelajaran tematik merupakan sistem pembelajaran yang memungkinkan peserta didik baik secara individual ataupun kelompok aktif mencari, menggali, dan menemukan konsep/prinsip keilmuan secara holistik, bermakna, dan autentik yang dihubungkan dan dikaitkan melalui tema tertentu. Sedangkan menurut Setiamihardja (2009) menyatakan bahwa pembelajaran tematik adalah pembelajaran yang menggunakan tema dalam mengaitkan beberapa muatan pelajaran yang saling berkaitan sehingga dapat memberikan pengalaman bermakna kepada peserta didik. Namun demikian pada kurikulum 2013 revisi 2018, muatan pelajaran Matematika dan PJOK sudah terpisah dari pembelajaran tematik dan berdiri sendiri dengan jam pembelajaran tersendiri.

Kurikulum 2013 sudah mulai disosialisasikan dan dilaksanakan sejak tahun 2013, namun dalam pelaksanaan dan implementasi pembelajaran di lapangan, guru masih kesulitan dalam membuat suatu pembelajaran yang terpadu, pembelajaran masih terpisah antar muatan pelajarannya. Selain itu 
dalam perencanaan pembelajaran juga masih sama dengan buku guru yang beredar di lapangan serta masih berpusat pada guru (teacher centered learning).

Pembelajaran yang baik dan berhasil dimulai dari penyusunan perangkat pembelajaran yang baik, sistematis, dan lengkap. Pembelajaran yang berkualitas dan bermakna berasal dari perencanaan pembelajaran yang baik. Perencanaan pembelajaran (lesson plan) dimaknai sebagai persiapan mengajar, namun mengajar bukan sebagai transfer knowledge atau menyampaikan ilmu atau materi kepada peserta didik, tetapi lebih pada menjadikan peserta didik belajar. Belajar yang dimaksud merupakan perubahan tingkah laku, sikap, pengetahuan, maupun keterampilan yang disengaja ke arah positif untuk tujuan tertentu. Tujuannya dengan rencana pembelajaran yang baik maka peserta didik mempunyai pengalaman belajar yang bermakna serta mampu mencapai tujuan pembelajaran yang ditetapkan, namun tetap mempertimbangkan karakteristik peserta didik. Menurut pendapat Prastowo (2013), perencanaan pembelajaran merupakan suatu cara yang memuaskan disertai dengan langkahlangkah antisipatik untuk membuat pembelajaran dapat berjalan dengan baik, sehingga dapat membentuk watak, peradaban, dan meningkatkan mutu kehidupan peserta didik.

Berdasarkan sudut pandang tersebut, maka dalam membuat perencanaan pembelajaran harus sesuai dengan konsep pendidikan dan pembelajaran yang tertuang dalam kurikulum yang berlaku dan digunakan pada saat itu. Penyusunan perencanaan pembelajaran dengan memperhatikan berbagai aspek bertujuan agar pelaksanaan pembelajaran berjalan dengan efektif dan efisien. Setiap guru wajib menyusun suatu perangkat pembelajaran secara lengkap dan sistematis agar pembelajaran berlangsung secara interaktif, inspiratif, menyenangkan, menantang, memotivasi peserta didik untuk berpartisipasi aktif, bervariasi, serta memberikan ruang yang cukup bagi penyampaian ide, prakarsa, kreativitas, dan kemandirian sesuai dengan bakat, minat, dan perkembangan fisik serta psikologis peserta didik.

Kebermaknaan pembelajaran salah satunya yaitu peserta didik dapat berfikir tingkat tinggi terutama dalam pemecahan masalah yang dicapai melalui berbagai kegiatan belajar. Pembelajaran yang menekankan pada keterampilan peserta didik berfikir tingkat tinggi dikenal dengan pembelajaran berbasis HOTS (Higher of Order Thinking Skills). Pada implementasinya, penerapan pembelajaran HOTS bukan hal yang mudah dilaksanakan oleh guru. Guru hanya memahami bahwa pembelajaran HOTS merupakan pembelajaran yang menyediakan soal yang sulit dikerjakan oleh sebagian besar peserta didik. Dalam mengimplementasikan pembelajaran HOTS, seorang guru harus benar-benar menguasai materi dan strategi pembelajaran, serta dapat menyesuaikan pembelajaran dengan lingkungan dan kompetensi (intake) peserta didik. Terkadang guru sudah berusaha maksimal dalam membuat suatu pembelajaran agar menarik bagi peserta didik, tetapi respon para peserta didik tetap saja dingin, dan relatif pasif.

Guru diharapkan mampu menyusun kegiatan belajar yang mengimplementasikan pembelajaran HOTS agar peserta didik tidak hanya melakukan kegiatan pembelajaran pada level 1 yaitu C-1 (mengetahui), C-2 (memahami), level 2 yaitu C-3 (menerapkan), tetapi juga pada level 3 yaitu C-4 (sintesis/analisis), C-5 (evaluasi) 
dan C-6 (berkreasi). Pembuatan soal HOTS pada pembelajaran bertujuan agar peserta didik terbiasa berfikir divergen (menyebar) dan tidak berfikir konvergen (terpusat). Berfikir divergen ini dimaksudkan peserta didik tidak hanya menjawab soal secara benar, namun bagaimana peserta didik mampu memikirkan beberapa analisis jawaban dari permasalahan yang ada pada soal.

Pembelajaran HOTS salah satu cirinya yaitu membuat peserta didik dapat berfikir secara divergen, dengan beberapa kemungkinan dan alternatif jawaban dan pemikiran yang bervariasi. Karena dengan pembiasan-pembiasan pembelajaran selama ini untuk berfikir konvergen dengan hanya satu jawaban dan satu cara pengerjaan yang benar, maka akan membunuh kreativitas peserta didik dalam berfikir. Peserta didik yang cenderung berfikir konvergen, akan tumbuh menjadi manusi yang takut gagal dan takut berbuat kesalahan. Hal ini akan menjadikan peserta didik kurang kreatif dan kurang berinovasi.

Berdasarkan observasi awal yang dilakukan peneliti pada tanggal $17-20$ September 2018 di SD Muhammadiyah 5 Batu diperoleh hasil bahwa SD tersebut masih baru dalam melaksanakan kurikulum 2013. Karena masih dalam tahap adaptasi/ penyesuaian, maka kurikulum 2013 melalui pembelajaran tematik masih dilaksanakan pada kelas I dan kelas IV. Menurut hasil wawancara dengan guru kelas I dan kelas IV, dalam menyusun perangkat pembelajaran guru masih mengalami kesulitan dalam memadukan beberapa muatan pelajaran dalam suatu tema. Hal ini dibuktikan pada saat observasi diperoleh temuan bahwa perangkat pembelajaran yang terdapat pada tempat penelitian diperoleh dari Dinas Pendidikan bukan perangkat pembelajaran yang dibuat oleh guru sendiri sesuai dengan kebutuhan pembelajaran di kelas.

Perangkat pembelajaran yang tersedia di SD Muhammadiyah 5 Batu kurang memperhatikan pembelajaran yang HOTS (Higher of OrderThinking Skills), hal ini dibuktikan berdasarkan Kata Kerja Operasional (KKO) yang terdapat pada perangkat pembelajaran masih banyak menggunakan KKO dari C1 - C3. Data awal tersebut didukung dengan observasi pembelajaran, bahwa dalam pembelajaran guru kurang menekankan pembelajaran yang HOTS dibuktikan dengan dalam pembelajaran peserta didik hanya disuruh mengerjakan berbagai soal yang disediakan, serta kegiatan pembelajaran kurang bervariasi.

Analisis kebutuhan penyusunan perangkat pembelajaran tematik berbasis HOTS ini meliputi analisis kurikulum meliputi Kompetensi Inti (KI) dan Komepetensi Dasar (KD), analisis karakteristik peserta didik, serta analisis situasi lapangan. Analisis pada berbagai aspek dilakukan untuk mengetahui kebutuhan perlu dikembangkannya perangkat pembelajaran dalam bentuk RPP tematik berbasis HOTS yang menyeluruh dan komprehensif sesuai dengan kondisi peserta didik, kurikulum, serta situasi di lapangan. Analisis kebutuhan yang menyeluruh dan akurat diharapkan dapat dikembangkan perangkat pembelajaran tematik berbasis HOTS yang sesuai dengan kebutuhan lapangan.

\section{METODE}

Penelitian ini menggunakan jenis penelitian kualitatif, yang merupakan metode penelitian untuk meneliti pada kondisi obyek yang alamiah (tanpa perlakuan khusus yang sengaja diubah) (Sugiyono, 2014: 1). Pendekatan penelitian yang dipilih peneliti yaitu 
pendekatan deskriptif. Pendekatan deskriptif digunakan berdasarkan pertimbangan bahwa permasalahan yang akan diteliti sedang berlangsung pada masa sekarang yang bertujuan untuk menganalisa peristiwa-peristiwa yang terjadi di lapangan kemudian diungkapkan dalam bentuk narasi dan deskripsi.

Karena menggunakan pendekatan deskriptif, maka kehadiran peneliti di lokasi penelitian atau di lapangan sangat diperlukan. Hal ini dkarenakan peneliti sebagai instrumen kunci yang berusaha merekam segala kejadian dan peristiwa yang terjadi di lapangan. Selain itu, peneliti juga berusaha menyesuaikan diri dengan situasi dan kondisi yang ada di lapangan tanpa memberikan suatu perlukuan khusus yang dibuat dengan sengaja, serta berusaha untuk menciptakan hubungan baik dengan informan yang terkait dengan penelitian.

Sumber data pada penelitian ini diperoleh dari informan dianggap paling penting untuk mengetahui secara rinci dan jelas mengenai fokus penelitian, yaitu terkait penyusunan perangkat pembelajaran tematik pada kurikulum 2013. Informan tersebut yaitu Kepala Sekolah SD Muhammadiyah 05 Batu, semua guru kelas dari kelas I sampai guru kelas VI. Adapun prosedur penelitian yang dilakukan peneliti meliputi tahap persiapan, tahap pelaksanaan, hasil temuan penelitian, dan tahap pelaporan.

Peneliti ini menggunakan tiga teknik untuk memperoleh data di lapangan yaitu: teknik wawancara, observasi dan dokumentasi. Uji kebasahan data menggunakan triangulasi yaitu triangulasi teknik dan triangulasi sumber. Analisis data dalam penelitian ini mengacu pada analisis kualitatif yang dinyatakan oleh Miles dan Huberman. Adapun tahapan yang digunakan dalam melakukan analisa data yaitu: data reduction (reduksi data), data display (penyajian data), conclusion and verifying (kesimpulan dan verifikasi data) (Miles \& Hubberman: 1992: 16-21).

\section{HASIL DAN PEMBAHASAN}

\section{Analisis Kurikulum}

Berdasarkan hasil penelitian yang dilakukan pada tanggal 29 Maret 2019, diketahui bahwa SD Muhammadiyah 5 Batu sudah melaksanakan kurikulum 2013. Akan tetapi, pelaksanaan kurikulum 2013 baru berlangsung selama kurang lebih dua tahun. Kurikulum 2013 baru terlaksana di kelas 1 dan kelas 4 di tahun 2018, namun sekarang SD Muhammadiyah 5 Batu sudah melaksanakan pembelajaran tematik di setiap jenjang kelas. Namun demikian, masih banyak adaptasi yang dilakukan sekolah terkait penerapan kurikulum 2013. Kurikulum 2013 yang digunakan di SD Muhammadiyah 5 Batu sudah menyesuaikan dengan anjuran pemerintah yaitu menggunakan kurikulum 2013 edisi revisi, dimana muatan pelajaran Matematika dan PJOK sudah terpisah tidak masuk dalam pembelajaran tematik.

Terkait penerapan kurikulum 2013, guru SD Muhammadiyah 5 Batu masih terus berproses untuk bisa menerapkan sesuai konsep yang seharusnya dalam suatu bentuk pembelajaran terpadu, bermakna, dan sesaui dengan kebutuhan dan karakterstik peserta didik. Apabila merujuk pada konsep kurikulum 2013 yang menekankan pada pembelajaran yang berpusat pada peserta didik dengan mengembangkan tingkat kemampuan berpikir peserta didik, maka perlu bagi guru memahami kelengkapan perangkat pembelajaran yang HOTS (Higher of Order Thinking Skills). Ada banyak komponen dalam kurikulum 2013 yang harus menjadi perhatian guru dalam melaksanakan pembelajaran. Guru 
seharusnya menerapkan kurikulum 2013 melalui pembelajaran tematik tidak hanya berbasis pada hasil namun proses, sehingga dengan adanya pembelajaran HOTS peserta didik tidak hanya belajar konsep tetapi penerapan praktis.

Analisis kurikulum 2013 dimulai dengan analisis KI di kelas rendah dan di kelas tinggi. Adapun hasil analisis Kompetensi Inti (KI) sebagai beikut:

Tabel 2. Kompetensi Inti (KI) Pengetahuan dan Keterampilan untuk Jenjang Sekolah Dasar (SD)

\begin{tabular}{|c|c|}
\hline \multicolumn{2}{|l|}{ KELAS RENDAH } \\
\hline $\begin{array}{c}\text { KOMPETENSI INTI } 3 \\
\text { (PENGETAHUAN) }\end{array}$ & $\begin{array}{c}\text { KOMPETENSI INTI } 4 \\
\text { (KETERAMPILAN) }\end{array}$ \\
\hline $\begin{array}{l}\text { Memahami pengetahuan } \\
\text { faktual dengan cara } \\
\text { mengamati (mendengar, } \\
\text { melihat, membaca) dan } \\
\text { menanya berdasarkan } \\
\text { rasa ingin tahu tentang } \\
\text { dirinya, makhluk ciptaan } \\
\text { Tuhan dan kegiatannya, } \\
\text { dan benda-benda yang } \\
\text { dijumpainya di rumah dan } \\
\text { di sekolah. }\end{array}$ & $\begin{array}{l}\text { Menyajikan pengetahuan } \\
\text { faktual dalam bahasa yang } \\
\text { jelas, sistematis dan logis, } \\
\text { dalam karya yang estetis, } \\
\text { dalam gerakan yang } \\
\text { mencerminkan anak sehat, } \\
\text { dan dalam tindakan yang } \\
\text { mencerminkan perilaku } \\
\text { anak beriman dan } \\
\text { berakhlak mulia }\end{array}$ \\
\hline \multicolumn{2}{|l|}{ KELAS TINGGI } \\
\hline $\begin{array}{l}\text { KOMPETENSI INTI } 3 \\
\text { (PENGETAHUAN) }\end{array}$ & $\begin{array}{l}\text { KOMPETENSI INTI } 4 \\
\text { (KETERAMPILAN) }\end{array}$ \\
\hline $\begin{array}{l}\text { Memahami pengetahuan } \\
\text { faktual dengan cara } \\
\text { mengamati dan menanya } \\
\text { berdasarkan rasa ingin } \\
\text { tahu tentang dirinya, } \\
\text { makhluk ciptaan Tuhan } \\
\text { dan kegiatannya, dan } \\
\text { benda-benda yang } \\
\text { dijumpainya di rumah, di } \\
\text { sekolah dan di tempat } \\
\text { bermain }\end{array}$ & $\begin{array}{l}\text { Menyajikan pengetahuan } \\
\text { faktual dalam bahasa yang } \\
\text { jelas, sistematis dan logis, } \\
\text { dalam karya yang estetis, } \\
\text { dalam gerakan yang } \\
\text { mencerminkan anak sehat, } \\
\text { dan dalam tindakan yang } \\
\text { mencerminkan perilaku } \\
\text { anak beriman dan } \\
\text { berakhlak mulia. }\end{array}$ \\
\hline
\end{tabular}

Sumber : Permendikbud No. 37 Tahun 2018

Berdasarkan hasil analisis Kompetensi Inti (KI) untuk kelas rendah dan kelas tinggi dapat disimpulkan bahwa untuk aspek pengetahuan antara kelas rendah dan kelas tinggi ada sedikit perbedaan. Perbedaan ini terlihat dari ruang lingkupnya, untuk kelas rendah ruang lingkup pembelajarannya di rumah dan di sekolah, sedangkan untuk kelas tinggi ruang lingkupnya lebih luas lagi yaitu di rumah, di sekolah, dan di tempat bermain. Temuan yang lain yaitu bahwa ruang lingkup pembelajaran untuk peserta didik jenjang Sekolah Dasar (SD) disesuaikan dengan lingkungan sekitar peserta didik, sehingga dalam pembelajarannya mengimplementasikan contextual learning.

Aspek keterampilan pada Kompetensi Inti (KI) untuk kelas rendah dan kelas tinggi sama. Namun demikian dalam pengimplementasiannya pada pembelajaran taraf kesulitan dan kekompleksitasannya berbeda. Peserta didik untuk kelas tinggi lebih sulit dan lebih bervariasi daripada untuk peserta didik di kelas yang lebih rendah.

Hasil temuan lain berdasarkan analisis KD semua muatan pelajaran tematik diketahui bahwa semua KD mengharuskan peserta didik dapat mencapai kemampuan berfikir tingkat tinggi atau HOTS (Higher Order Thinking Skills). Hal ini terlihat pada aspek keterampilan atau psikomotorik peserta didik harus memiliki kompetensi dalam menyelesaikan masalah, membuat, menganalisis, mengorganisasikan, serta menyajikan yang merupakan bentukbentuk Kata Kerja Operasional (KKO) pada tingkatan C4 - C6. Dari berbagai keterampilan yang harus dikuasai oleh peserta didik maka peserta didik akan memperoleh berbagai konsep pengetahuan yang bermakna dalam kehidupan peserta didik.

Dapat disimpulkan bahwa apabila peserta didik dapat memperoleh pembelajaran bermakna serta mampu mencapai kompetensi pada tahap HOTS, maka pembelajaran yang dilakukan juga harus bertahap mulai dari LOTS (Low Order Thinking Skills) dan bertahap 
sampai tahap HOTS. Jadi pembelajaran yang dilaksanakan tidak hanya membangun pengetahuan peserta didik pada tahap C1 - C3 namun bertahap pada C4 - C6. Selain pembelajaran yang HOTS, penilaian pembelajaran yang dilakukan juga harus mengarah pada penilaian HOTS. Penilaian HOTS tidak hanya pada aspek kognitif (C4 - C6), namun juga afektif (A3 - A5) dan psikomotorik (P4 P5).

\section{Analisis Peserta didik}

Peserta didik kelas V SD yaitu peserta didik yang berusia kira-kira antara $10-11$ tahun yang masuk dalam masa kanakkanak akhir. Pada usia tersebut berdasarkan teori perkembangan Piaget masuk dalam tahap concrete operational thought atau pemikiran konkretoperasional (Desmita, 2010: 35). Peserta didik pada tahap perkembangan ini mempunyai pemikiran yang terbatas dengan hal-hal yang konkret, benda-benda yang benar-benar nyata. Sebaliknya, benda atau peristiwa yang tidak ada hubungannya secara jelas dengan kenyataan, akan sulit dipikirkan oleh peserta didik.

Pada pembelajaran peserta didik kelas V SD perlu dikembangkan pembelajaran dengan konstruktivisme sosial. Menurut pendapat Vygotsky (dalam Thobroni \& Mustofa, 2013: 112) mengembangkan konstruktivisme sosial yang memiliki pengertian bahwa belajar bagi peserta didik dilakukan dalam interaksi dengan lingkungan sosial maupun fisiknya. Penemuan dalam belajar lebih mudah diperoleh dalam konteks budaya seseorang. Dengan pengalaman langsung yang diperoleh peserta didik, maka peserta didik akan membangun pemahamannya sendiri.

SD Muhammadiyah 5 Batu memiliki 6 rombel dengan total 86 peserta didik yang terdiri dari 43 peserta didik laki-laki dan 43 peserta didik perempuan. Peserta didik memiliki latar belakang dan karakteristik yang beragam. Peserta didik berada di lingkungan dengan latar belakang keluarga dan pekerjaan orang tua yang berbeda-beda. Adanya latar belakang yang berbeda-beda tentunya juga berpengaruh pada gaya dan kemampuan belajar peserta didik. Terdapat peserta didik dengan kemampuan tinggi, sedang dan juga rendah. Melihat hal tersebut, maka guru harus memperhatikan bagaimana pengkondisian peserta didik dalam pembelajaran. Dengan adanya kemampuan dan gaya belajar yang berbeda dibutuhkan pembelajaran yang berbeda yang mampu mewadahi semua kemampuan dan gaya belajar tersebut. Artinya semua peserta didik harus mencapai tujuan belajar yang sama namun peserta didik harus diberikan kegiatan belajar yang berneda sesuai dengan kemampuan peserta didik. Penyusunan perangkat pembelajaran yang selama ini disusun oleh guru belum memenuhi karakteristik dan kebutuhan peserta didik dalam pembelajaran. Adanya karakteristik dan latar belakang peserta didik yang beragam menuntut guru untuk dapat kreatif dan inovatif dalam pembelajaran.

Seperti halnya menurut pendapat Rusman (2012: 25-252) bahwa peserta didik usia SD/MI ketika belajar mempunyai tiga karakteristik yang menonjol yaitu konkret, integratif, dan hierarkis. Konkret disini berarti pemanfaatan lingkungan secara optimal untuk pencapaian proses dan hasil belajar yang berkualitas. Integratif maksudnya memandang sesuatu yang dipelajari sebagai suatu keutuhan dan terpadu. Karakteristik terakhir yaitu hierarkis yang berarti berkembang secara bertahap dari hal-hal yang sederhana ke hal-hal yang lebih kompleks. 


\section{Analisis Studi Lapangan}

SD Muhammadiyah 5 Batu sebagai sekolah mitra baru mulai melaksanakan kurikulum 2013. Berdasarkan observasi awal yang dilakukan peneliti pada tanggal 17 - 20 September 2018 di SD Muhammadiyah 5 Batu diperoleh hasil bahwa sekolah masih dalam tahap adaptasi/ penyesuaian, maka kurikulum 2013 melalui pembelajaran tematik masih dilaksanakan pada kelas I dan kelas IV. Menurut hasil wawancara dengan guru kelas I dan kelas IV, dalam menyusun perangkat pembelajaran guru masih mengalami kesulitan dalam memadukan beberapa muatan pelajaran dalam suatu tema. Hal ini dibuktikan pada saat observasi diperoleh temuan bahwa perangkat pembelajaran yang terdapat disana merupakan perangkat pembelajaran yang diperoleh dari Dinas Pendidikan bukan perangkat pembelajaran yang dibuat oleh guru sesuai dengan kebutuhan pembelajaran di kelas.

Perangkat pembelajaran yang tersedia di SD Muhammadiyah 5 Batu kurang memperhatikan pembelajaran yang HOTS (Higher of Order Thinking Skills), hal ini dibuktikan berdasarkan Kata Kerja Operasional (KKO) yang terdapat pada perangkat pembelajaran masih banyak menggunakan KKO dari C1 - C3. Kata Kerja Operasional yang sering digunakan dalam perangkat pembelajaran yang telah disusun guru hanya sekitar C1 dan C2 yang hanya mengakomodasi kemampuan mengingat kembali (recall) dari peserta didik, yaitu menyebutkan, menjelaskan, menuliskan kembali, mendefinisikan. Karena tujuan pembelajaran yang harus dicapai hanya pada level 1 , maka kegiatan pembelajaran yang direnvanakan pada RPP juga terkesan monoton dan kurang bervariasi, juga kurang mengakomodasi semua gaya belajar peserta didik. Secara garis besar kegiatan yang disusun guru dalam RPP merujuk pada pembelajaran dari umum ke khusus yaitu siswa dijelaskan tentang suatu konsep kemudian diimlemntasikan pada suatu soal untuk diselesaikan. Hal ini akan membuat konsep yang diberikan kepada peserta didik kurang bermakna dan akan cenderung mudah dilupakan. Berbeda sekali jika peserta didik menemukan suatu konsep itu sendiri melalui kegiatan pembelajaran yang bermakna dan mengkonstruksi pengetahuannya sendiri.

Pada soal evaluasi yang ada dalam RPP yang telah dibuat guru, berdasarkan hasil analisis diperoleh temua bahwa soal evaluasi mayoritas menggunakan pertanyaan dengan satu jawaaban tunnggal, jarang sekali diberi permasalahan yang harus diselesaikan peserta didik, serta kurang menggambarkan lingkungan sekitar siswa. Hal ini menyebabkan peserta didik yang menjawab salah, akan mendapat penilaian rendah. Berbeda jika soal yang dikembangkan merupakan soal HOTS yang tidak hanya satu jawaban benar, peserta didika akan dapat mengembangkan kemamppuan berfikirnya sesuai dengan pengalaman dan analisisnya, sehingga bagaimanapun jawaban yang diberikan dapat diapresiasi oleh guru.

Analisis studi lapangan dilakukan juga untuk mengetahui pembelajaran tematik yang dilaksanakan di SD Muhammadiyah 5 Batu. Analisis pembelajaran ini diperoleh dari analisis landasan teori tentang pembelajaran tematik serta kondisi pembelajaran tematik secara nyata di lapangan. Kesenjangan antara kondisi ideal dan kondisi di lapangan ini yang kemudian dianalisis menjadi suatu permasalahan yang perlu dipecahkan. Berikut dipaparkan mengenai kondisi ideal dan kondisi di lapangan dari pembelajaran tematik. 
Tabel 2. Analisis Kondisi Ideal dan Kondisi di Lapangan dari Pembelajaran Tematik

\begin{tabular}{|c|c|c|}
\hline No. & Kondisi Ideal & Kondisi di Lapangan \\
\hline 1. & $\begin{array}{l}\text { Memberikan } \\
\text { pengalaman dan } \\
\text { kegiatan belajar } \\
\text { sangat relevan } \\
\text { dengan tingkat } \\
\text { perkembangan } \\
\text { peserta didik. }\end{array}$ & $\begin{array}{l}\text { Dalam } \\
\text { pembelajaran, } \\
\text { terpusat pada buku } \\
\text { teks terbitan } \\
\text { Kemendikbud. }\end{array}$ \\
\hline 2. & $\begin{array}{l}\text { Menyenangkan, } \\
\text { karena bertolak } \\
\text { dari minat dan } \\
\text { kebutuhan anak. }\end{array}$ & $\begin{array}{l}\text { Guru kesulitan } \\
\text { menggunakan buku } \\
\text { teks terkait } \\
\text { kegiatan yang tidak } \\
\text { ada di lingkungan } \\
\text { sekitar. }\end{array}$ \\
\hline 3. & $\begin{array}{l}\text { Hasil belajar dapat } \\
\text { bertahan lama } \\
\text { karena lebih } \\
\text { berkesan dan } \\
\text { bermakna. }\end{array}$ & $\begin{array}{l}\text { Pengalaman yang } \\
\text { diberikan peserta } \\
\text { didik dalam } \\
\text { kegiatan } \\
\text { pembelajaran } \\
\text { kurang kontekstual } \\
\text { dan kurang sesuai } \\
\text { dengan lingkungan } \\
\text { peserta didik. }\end{array}$ \\
\hline 4. & $\begin{array}{l}\text { Mengembangkan } \\
\text { keterampilan } \\
\text { berpikir peserta } \\
\text { didik sesuai dengan } \\
\text { permasalahan yang } \\
\text { dihadapi. }\end{array}$ & $\begin{array}{l}\text { Hasil belajar kurang } \\
\text { berkesan dan } \\
\text { kurang bermakna } \\
\text { karena peserta } \\
\text { didik menganggap } \\
\text { pembelajaran } \\
\text { merupakan sesuatu } \\
\text { yang harus } \\
\text { diselesaikan bukan } \\
\text { yang dibutuhkan. }\end{array}$ \\
\hline 5. & $\begin{array}{l}\text { Menyajikan } \\
\text { kegiatan yang } \\
\text { bersifat pragmatis } \\
\text { sesuai dengan } \\
\text { permasalahan yang } \\
\text { ditemui. }\end{array}$ & $\begin{array}{l}\text { Kegiatan } \\
\text { pembelajaran masih } \\
\text { banyak bersifat } \\
\text { teoritis, dan } \\
\text { konseptual, dan } \\
\text { kurang } \\
\text { mengembangkan } \\
\text { cara berfikir } \\
\text { peserta didik secara } \\
\text { divergen karena } \\
\text { masih cenderung } \\
\text { konvergen. }\end{array}$ \\
\hline
\end{tabular}

Berdasarkan paparan perbandingan antara kondisi ideal dan kondisi di lapangan pembelajaran tematik, kesenjangan yang terjadi antara dua kondisi tersebut menimbulkan permasalahan. Permasalahan pembelajaran tematik yang terjadi yaitu pembelajaran belum mengembangkan keterampilan berfikir peserta didik, pembelajaran cenderung membiasakan peserta didik berfikir secara konvergen bukan secara divergen, pembelajaran belum bersifat pragmatis namun masih konseptual dan teoritisa sehingga kurang bermakna bagi peserta didik.

Dapat disimpulkan bahwa SD Muhammadiyah 5 Batu sudah menerapkan kurikulum terbaru yang ditentukan pemerintah yaitu kurikulum 2013 meskipun belum terlaksana secara maksimal. Guru-guru masih belum sepenuhnya memahami penerapan dari kurikulum 2013. Perangkat pembelajaran yang dibuat guru juga belum sesuai dengan konsep K13 yaitu menekankan pada tingkat berpikir HOTS (Higher of Order Thinking Skills). Menurut konsep K13 diharapkan dapat memberikan pengalaman belajar secara langsung dengan mencakup kemampuan kognitif, afektif, dan psikomotor (Kemendikbud, 2013).

Selain itu, pelaksanaan pembelajaran harus dapat mencapai tujuan yang diharapkan. Menurut Sanjaya (2014:86) bahwa tujuan pembelajaran adalah kemampuan (kompetensi) atau keterampilan yang diharapkan dapat dimiliki oleh peserta didik setelah mengikuti proses pembelajaran. Untuk dapat mencapai tujuan pembelajaran secara maksimal maka guru perlu memperhatikan bagaimana perangkat pembelajaran yang disusun dapat memenuhi kondisi pembelajaran yang ada. Oleh karena itu penting bagi guru untuk 
dapat menyusun perangkat pembelajaran yang berkualitas.

\section{KESIMPULAN DAN SARAN}

\section{Kesimpulan}

Adapun kesimpulan dari berbagai analisis yang telah dilakukan, yaitu sebagai berikut:

1. Berdasarkan analisis kurikulum, diperoleh temuan bahwa ruang lingkup pembelajaran pada jenjang SD hanya sampai di rumah, di sekolah, dan di rumah yang merupakan lingkungan sekitar siswa. Indikator ketercapaian pembelajaran sudah masuk pada level 3 yaitu mulai $\mathrm{C} 4$ sampai $\mathrm{C6}$.

2. Berdasarkan analisis peserta didik, diperoleh temuan bahwa peserta didik di jenjang Sekolah Dasar (SD) pada tahap operasional konkret, yang belajar secara holistik, komprehensif, dan kontekstual.

3. Hail temuan pada analisis kondisi lapangan diperoleh berdasarkan analisis RPP yang telah disusun guru serta kondisi pembelajaran tematik. Disimpulkan bahwa terjadi permaslahan dalam pembelajaran karena pembelajaran belum mengembangkan keterampilan berfikir peserta didik, pembelajaran cenderung membiasakan peserta didik berfikir secara konvergen bukan secara divergen, pembelajaran belum bersifat pragmatis namun masih konseptual dan teoritisa sehingga kurang bermakna bagi peserta didik.

Berdasarkan hasil temuan tersebut, guru memerlukan perangkat pembelajaran tematik kurikulum 2013 yang mencakup tingkat berfikir HOTS (Higher Order Thinking Skills) agar pelaksanaan pembelajaran berjalan secara optimal. Dengan adanya perencaan pembelajaran yang berbasis HOTS, maka implementasi pembelajaran yang dilakukan guru di kelas harapannya juga merupakan pembelajaran HOTS, sehingga penilaian yang dilakukan juga menggunakan penilaian dan soal HOTS.

\section{Saran}

Berdasarkan hasil penelitian yang telah dilaksanakan di SD Muhammadiyah 5 Batu ada beberapa saran yang bisa diberikan untuk penelitian selanjutnya. Rekomendasi dan saran yang dapat diberikan berdasarkan hasil penelitian ini yaitu 1) perlu diadakan workshop dan pelatihan untuk penyusunan perangkat pembelajaran tematik pada kurikulum 2013 berbasis HOTS; 2) perlu melihat keefektifan dan keefisien implementasi perangkat pembelajaran tematik pada kurikulum 2013 berbasis HOTS yang disusun; dan 3) diadakan penelitian lanjutan berdasarkan temuan yang diperoleh pada penelitian ini.

\section{Daftar Pustaka}

[1] Akbar, S. 2013. Instrumen Perangkat Pembelajaran. Bandung: PT. Remaja Rosdakarya.

[2] Desmita. 2010. Psikologi Perkembangan Peserta Didik Panduan bagi Orang Tua dan Guru dalam Memahami Psikologi Anak Usia SD, SMP, dan SMA. Bandung: PT Remaja Rosdakarya.

[3] Permendikbud No. 37 Tahun 2018 tentang Perubahan Atas Peraturan Menteri Pendidikan Dan Kebudayaan Nomor 24 Tahun 2016 Tentang Kompetensi Inti dan Kompetensi Dasar Pelajaran Pada Kurikulum 2013 Pada Pendidikan Dasar dan Pendidikan Menengah.

[4] Miles, M. B. \& Hubberman, A.M. 1992. Analisis Data Kualitatif: Buku Sumber Tentang Metode-metode Baru Terjemahan Tjetjep Rohendi Rohidi. Jakarta: Universitas Indonesia Press. 
[5] Setiamihardja, R. 2009. Pendekatan Tematik di Kelas I Sekolah Dasar. Jurnal Pendidikan Dasar. Nomor 11- April 2009: 42-46.

[6] Sugiyono. 2010. Metode Penelitian Pendidikan Pendekatan Kuantitatif, Kualitatif, dan R\&D. Bandung: Alfabeta.

\section{Profil Penulis}

Penulis pertama bernama Tyas Deviana, M.Pd merupakan dosen PGSD Universitas Muhammadiyah Malang. Penulis Lahir di Tulungagung, 28 Desember 1988. Pendidikan Sarjana ditempuh di Universitas Negeri Malang dengan mengambil Program Studi PGSD lulus tahun 2011. Penulis melanjutkan pendidikan pada Program Kuliah Kewenangan Tambahan (KKT) dengan jurusan Bimbingan Konseling (BK) di Universitas Negara Malang lulus tahun 2012. Pada jenjang Magister, penulis melanjutkan pendidikannya di Universitas Negeri Malang dengan mengambil jurusan yang linier yaitu
[7] Rusman. 2012. Model-model Pembelajaran: Mengembangkan Profesionalisme Guru. Jakarta: Rajagrafindo Persada.

[8] Undang-Undang No. 20 tahun 2003 tentang Sistem Pendidikan Nasional

Pendidikan Dasar (Dikdas) konsentrasi Guru Kelas lulus tahun 2015.

Penulis kedua bernama Dian Ika Kusumaningtyas M.Pd merupakan dosen PGSD Universitas Muhammadiyah Malang. Penulis Lahir di Ponorogo, 24 Maret 1991. Pendidikan Sarjana ditempuh di Universitas Negeri Malang dengan mengambil Program Studi PGSD lulus tahun 2013. Pada jenjang Magister, penulis melanjutkan pendidikannya di Universitas Negeri Malang dengan mengambil jurusan yang linier yaitu Pendidikan Dasar (Dikdas) konsentrasi Guru Kelas lulus tahun 2015. 